\title{
Interview: In-depth analysis of the Hong Kong security law and its implications
}

Edition 4, 2020

Professor Vivienne Bath

DOI: 10.37839/MAR2652-550X4.3

On June 30, the most powerful part of the Chinese government, the Standing Committee of the National People's Congress, passed with immediate effect the Law for Safeguarding National Security in the Hong Kong Special Administrative Region (HKSAR).

The Hong Kong National Security Law follows ongoing independence and prodemocracy protests, which in the second half of last year were the biggest ever in the history of the Chinese-controlled territory.

Vivienne Bath, Professor of Chinese and International Business Law and Director of the Centre for Asian and Pacific Law, University of Sydney, analyses the significance of the laws for Hong Kong, China and the international community. She spoke with Cathy Harper, Managing Editor, Melbourne Asia Review.

\section{What does the security law actually specify?}

The law is quite a comprehensive document and it has six chapters. It starts with General Principles (chapter I) and goes on to duties of the HKSAR government, and the establishment and responsibilities of HK government bodies which are responsible for the implementation of the law.

Chapter III sets out Offences and Penalties, which is what has attracted considerable interest, and the following chapters look at Jurisdiction of courts, applicable law and 
procedure, and the highly controversial establishment of the Office of Safeguarding Security in the Central People's Government of Hong Kong. In addition to national security offences there is quite a lot of other material that is really very significant in the context of the Hong Kong judicial system.

The General Principles set out what the law is meant to do, which is to implement the policy of 'one country, two systems' of former President Deng Xiaoping, safeguard national security, prevent, suppress and impose punishments for the offences of succession, subversion, terrorism and collusion and so on.

Chapter II covers the various government bodies which are going to have to be set up and implemented in order to put the law into effect. Its aim is to establish separate and distinct roles and personnel in the HK government which answer to the executive and are strongly influenced by Chinese officials. It also clearly requires the government of HKSAR to enforce the law, including by promoting national security education in schools and universities and through social media; which, it appears, they have already started doing, purging libraries and essentially changing history by examining what goes into school texts.

Article 12 requires the Hong Kong government to set up what is called the "Committee for Safeguarding National Security," which is led by the Chief Executive and is comprised of various senior government ministers and representatives of the Police. The Committee has a National Security Advisor, designated by the Chinese government, who provides advice and sits on all meetings. In addition, Article 16 requires the police force to set up a special department to safeguard national security, to be headed by someone essentially approved by the newly established Office for Safeguarding National Security of the Central People's Government in the HKSAR (Article 48). This special police department may recruit "qualified professionals and technical personnel from outside the HKSAR," which presumably means that Chinese national security personnel can be seconded directly. The law not only sets out what the police must do under the law, it also requires the establishment of a specialised prosecution division in the Department of Justice. 
Again, prosecutors of this division may be appointed only after consent of the Committee. A special fund will be established for this purpose, which is not subject to any existing restrictions in HK law.

These government structures are already different to the existing governmental structure of Hong Kong because the Chief Executive is clearly put in place as the head of all of this but the police get their own role in the legislation and this Chinese Office for Safeguarding National Security actually potentially gets quite a lot of power.

It's only when we've established this framework that we get into the actual offences, of which there are four: succession, subversion, terrorist activities and collusion. These are all very widely drawn and have a wide potential scope and application.

Let's first consider the question of who administers the law and has jurisdiction over the offences. Under Chapter IV, the HKSAR has jurisdiction and therefore (with some potential exceptions), so do the Hong Kong courts. However, unlike the standard procedure, the Chief Executive is directly involved in who hears national security cases, as she appoints a panel of judges from the District Court up to Court of Final Appeal, and from deputy judges or recorders (so quite low level), to handle national security cases. So it is potentially not just the regular panels of judges that hear these offences. Not surprisingly, this provision has caused some concern.

However, Chapter V sets up a Chinese Office for Safeguarding National Security in Hong Kong (which is, apparently, already up and running) and Article 55 provides that this Chinese Office can, with the approval of the Central Government, upon a request made by the Chief Executive, or by the Chinese Office itself, take jurisdiction over a case that is complex due to the involvement of a foreign country; because a serious situation occurs where the government the HKSAR cannot "effectively enforce" the law or a major and imminent threat to national security has occurred. If so, the case can actually be referred to Chinese prosecution and the Chinese courts. Although there is no extradition arrangement, this is generally construed to 
mean that the defendant could be taken off to China. The language of this Article is very wide, and the implications are very far-reaching.

\section{What do the offences mean for individuals in Hong Kong?}

It is clear the law is already having an impact because the police have gone around and arrested all sorts of people for national security offences. The law is not retrospective, so if you're going to be arrested for colluding or inciting or colluding with foreign bodies, committing sedition, encouraging terrorist acts you have to have a little bit of time to actually commit the offence. In fact, the police started rounding up people very promptly after the law came into effect before they'd really had any time at all to commit any offences, I would have thought. It will be interesting to see how those cases shape up when they actually finally go through the courts.

Certainly, the police have made a very strong statement as to their intention to implement the laws against activists of all kinds. If I was such an activist I would be very concerned about my safety.

One would have hoped that the police would show some restraint, but they do not seem to be doing so. As a result, a person who puts out a piece of paper saying "independence" is immediately picked up on the basis of their breaching the law. Jimmy Lai, publisher of the Apple Daily and strong pro-democrat, has been arrested. But there's nothing in the law that says you can't protest, it depends on how widely the law is read.

In terms of the offences themselves, you've got secession (Article 20) which is really separatism, separating Hong Kong from China. This is aimed at the proindependence movement (China is traditionally very concerned about "splittism".) Apart from this, the offence is really very wide and applies to someone who "organises, plans, commits or participates in" separatism and so on, "whether or not by force or threat of force with a view to committing succession or undermining national unification." That could potentially pick up just about anybody. Similarly, it is an offence to 'incite, assist, abet or provide pecuniary or other financial 
assistance' for the commission of the secession offence. On this basis, if you gave a donation then you'd also be guilty of an offence. The other offences are equally broadly expressed.

I think you have to remember that the impact at a prosecution level will depend very much how the courts read and apply the law. A very vaguely drafted offence in our legal system and the Hong Kong legal system generally means that the prosecution have to work hard to prove you committed the offence. In a Chinese court, experience with political offences indicates that this gives the court considerable scope to find you guilty. In principle, the burden of proof is not widely different between China and Hong Kong. In practice there are a whole range of human rights lawyers and human rights activists who have been pulled in on the basis of sedition or stealing state secrets and they're all convicted.

It will also be interesting to see how many of these offenders end up being referred to China for prosecution. This seems quite possible if the Chinese authorities are not satisfied with the response of the hand-picked Hong Kong panel of judges.

\section{What about foreigners in Hong Kong and, indeed, outside it?}

There are a couple of things about the application of the law. First, it has extraterritorial application, so doesn't just apply to offences committed in Hong Kong. It also applies to offences committed by permanent residents who are outside Hong Kong, which includes quite a few people, as well as offences committed "against" the HKSAR outside Hong Kong by anyone.

How could this apply? Hong Kong authorities could apply for your extradition, if there is a treaty in force (hence the suspension of various treaties by Australia and other countries). Potentially there could be an Interpol Red Notice issued so that if you travel you could be subject to being detained pending extradition. (You could be like the Australian footballer Hakeem al-Araibi who was transiting through Thailand and almost got himself packed up and sent off to Bahrain.) It could definitely have an impact on you if there was one of those warrants out for your arrest, no matter how 
ridiculous or unfounded you might think the charges are. The official Australian Department of Foreign Affairs and Trade travel advice for Hong Kong was recently updated and now recommends against travelling to Hong Kong, as the "full extent" of the National Security Law is not yet clear; and the US' advice is to reconsider travel to Hong Kong, and cites the PRC government carrying out 'arbitrary and wrongful detentions'.

There has been a lot of criticism of this law, and quite a lot of that has come from academics, inside and outside China, although fears have also been expressed about the implications of the law on freedom of speech and academic freedom. There's nothing in the law which says you can't criticise it unless you take the view that it is endangering national security in some way to do so. On the other hand, the authorities appear to be going through the libraries and the education curriculum to try to promote national security and prevent people from endangering national security. I think it is clear that, notwithstanding the statements in the law about human rights, freedom of speech generally in terms of Hong Kong is likely to be affected.

\section{How might the laws effect foreigners who are in Hong Kong for business reasons and how might it affect their business activities?}

China will be aiming for a positive business response to the laws, which will presumably have a suppressing effect on protests, which can be disruptive for business. But the law contains very sweeping powers in relation to warrants, searches and investigation. The United States' response in withdrawing Hong Kong's special status, would be making people ask whether Hong Kong is still a secure place in order to run their business and to hold their money and their finances. Personal safety might also be an issue if cases are transferred to China under the law.

What Hong Kong has really had to offer is that it's a safe haven, or it has always been perceived to be, a safe haven from China-people rely on the fact that they can 
get their disputes settled there, that they will not be arbitrarily detained and that they will be personally safe. You also see quite a few Chinese disputes in the Hong Kong courts because they have more confidence in the Hong Kong courts than in their own system. If you undermine that you're really eating away at one of the pillars of Hong Kong's prosperity.

\section{What's your assessment of whether the security laws indicate a significant escalation of Beijing's action on any kind of dissent?}

The Chinese have been cracking down on dissent all over China ever since China's President Xi Jinping came into power. There's the National Security Law passed in China in 2015, there's a national intelligence law, there's a cyber security law. National security is appearing in all sorts of legislation. For example, there has been a crack-down on the export of some technology, which could be sensitive on the basis of high-tech development grounds (following the US example). There has been a major crackdown on dissent in Xinjiang. Within China, the authorities do not tolerate dissent and they appear to have asked themselves why they should tolerate dissent in Hong Kong.

The Western assumption has always been that as people got wealthier and as you establish a more developed legal system, a better rule of law, better judges and so on, that you would have a more open society and people would feel freer to say what they thought. It did look for quite some time as though that was actually happening in China. People were freer to say what they thought and social media of course gave them many avenues to express their views and their comments.

It appears that the government, or the Communist Party in particular, has been dismayed at the fact that people, when they got the chance, expressed all sorts of views-a lot of dissent about corruption, environmental damage and all sorts of things came out. Xi Jinping is very old-school in terms of the way he's ruling, and he doesn't like criticism. He appears to interpret every bit of criticism as something which may turn into political disorder. 


\section{What is your analysis of Beijing's approach to Taiwan and what we can gather from its recent actions as to what it might do in the future?}

The Chinese regime does not like the current government in Taiwan. They don't like the way that the President has refused to commit to what they view as the status of Taiwan. In addition, the Chinese approach has been that Taiwan should sign up for 'one-country, two systems'. But it's clear that Taiwan is not very attracted to the 'one-country, two systems' way of reunifying with China (or reunifying with China at all), particularly after what's happened this year in Hong Kong. It just doesn't look like a good avenue for them, because they have a very strong and prospering democracy. I don't know if the Chinese feel strong enough or are inclined to try to take over Taiwan by military means. If I was a Taiwan businessperson with a business in China I would feel rather insecure because I would have thought that the next avenue would be for China to get at that population to show Taiwan how vulnerable they are.

Image: Hong Kong police. Credit: Gavin Anderson/Flickr 